\title{
DERADICALIZING RELIGIOUS EXTREMISM LINGUISTICALLY: AN INTERTEXTUAL APPROACH TO ISLAMIC EXTREMISTS' VIEW ON THE QUR'ANIC INTERPRETATION
}

\author{
Widhiya Ninsiana \\ State Islamic Institute Metro \\ Iringmulyo, Metro, Lampung, Indonesia, 34112 \\ E-mail: widhiya.ninsiana@metrouniv.ac.id
}

\begin{tabular}{c|c|c}
\hline Received: & Revised: & Approved: \\
02/05/2020 & $04 / 07 / 2020$ & $07 / 10 / 2020$ \\
\hline
\end{tabular}

DOI: https:/ / doi.org/10.32332/akademika.v25i2.2053

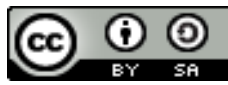

Deradicalizing Religious Extremism Linguistically: An Intertextual Approach To Islamic Extremists' View On The Qur'anic Interpretation

Licensed Under a Creative Commons Attribution-ShareAlike 4.0 Internasional License

\begin{abstract}
This article is a qualitative-descriptive study which employs which concern the existing phenomenon underlying in the translation of Qur'anic verses that are generally interpreted as a means for legitimizing the acts of terrorism by radical Islamists. The integration on the linguistic knowledge of Islamic texts has been studied as a process of incorporating new information into the existing knowledge with an interdisciplinary approach. The importance of language in the multitude of learning and the discipline of science has led to its status as a condition for correct understanding of the Qur'anic messages. This study used Fairclough's intertextual approach on the potentially abused Qur'anic verses for violence acts in the name of Islam by extremist groups such ISIS. Two patterns of understanding Islamic texts become the spectrum of how the teachings of Islam are fairly understood. Linguistic provides general criticism toward the radicals' interpretations in understanding the Islamic sources (primarily the Qur'anic verses). Then the study ends up with an argument that the radicalism in many groups in Islam is connected with the reality of Islamic sources which essentially needs to be interpreted in
\end{abstract}


the context of Islamic societies and requires dynamic reading and prospective production on the meanings of a sacred text.

Keywords: intertextuality, language, and radicalism

\section{A. Introduction}

Agus Rois in his book "Teror, Catatan Filsafat dan Politik tentang Firman dan Iman" reminds us in his writings since 9/11 when the skyscraper of the US business center exploded by the plane, instantly Islam and terrorism split into two related things and kept being asked up to now ${ }^{1}$. Since then, religious symbols carried by extremist actors disguise their political and economic disappointment. The perpetrators of terrorist acts allegedly born among the great tradition of fighting, namely liberalism and authoritarianism. Most of them young and educated people are trapped in a new world, amidst the unchallenged currents of modernization, with all the corruption and inequality. They were later provoked by the agenda of power. Thus, terrorism can "grow in mosques and study places converted into a place of political discussion". They also find strong language of resistance in literal religious texts ${ }^{2}$.

Islamic religious extremism uses the Qur'anic teachings about resistance and returns to the position of interpretation they find it difficult to use because of geopolitical nature ${ }^{3}$. However, Islam as a religion has texts that can be seen from different points of view. That is why the heterogeneity of interpretation is inevitable. The multi-interpretative religious text of the Muslims is interpreted in different interpreters' backgrounds. Its existence as a dead revelation (unable to speak) often appeals to the personal interests of its interpreters and their political interests ${ }^{4}$. The texts of the Qur'anic verses provide an opportunity for any group to be understood, let alone radical groups, which mostly partly and superficially interpret the Qur'anic verses ${ }^{5}$. The Quranic verses are often

${ }^{1}$ Agus Rois Khanifah, Teror, Catatan Filsafat Dan Politik Tentang Firman Dan Iman (Yogyakarta: Penerbit Makar, 2016).

2 Ana Serafim, “Terrorism - A Cultural Phenomenon?", Connections, 4, no. 1, (Spring 2005), p.61-74

${ }^{3}$ Amritha Venkatraman. (2007). "Religious Basis for Islamic Terrorism: The Quran and Its Interpretations", Studies in Conflict \& Terrorism, vol. 30, no.3: 229-248 19

${ }^{4}$ Makmun Rasyid, "HTI Gagal Paham Khilafah", (Pustaka Compass, 2016), p.

5 Nurdin Zuhdi, 'Hermeneutika Al-Qur'an: Tipologi Tafsir Sebagai Solusi Dalam Memecahkan Isu-Isu Budaya Lokal Keindonesiaan', Jurnal Esensia, 13.2 (2012). 
used to justify violence. One of verses is the chapter of At-Taubah verse no.5, "If it runs out of Haram month, kill the polytheists wherever you meet, catch them. Cage and intimate in the place of reconnaissance". In fact, one verse can be misinterpreted if interpreted separately from the verse before and after the verse. At Taubah verse 5 may not the only source to justify radical acts of terrorism, but it is also followed by another verse. "If they repent, establish prayers, pay zakat, give them freedom to walk ... And if the polytheists ask for protection, protect them to hear the word of God, then go to a safe place." Outside the thick verses will the interpretation of the violence, Islam contains many subtle verses and verses that support freedom. In fact, other verses which we should pay attention to says, "Whoever saved a life, he saved the lives of all men." Or an-Nisaa 29, "Do not you kill yourself because God loves you". These verses should be important lessons for suicide bombers. Hoffman ${ }^{6}$ (2017) commented on a religious terrorist, violence is first and foremost a sacramental act or divine obligation in direct response to theological demands. Terrorism takes on a transcendental aspect, and thus the perpetrators are not limited to political, moral or practical constraints"7

Discussing the potential role of linguistics in Islamic studies does not mean discussing linguistics whose birth comes from a missionary tradition, but rather on Islamic study activities and how the interpretation of misinterpreted Islamic sources from a linguistic point of view ${ }^{8}$. This article aims to describe the basis of Islamic Religion and the importance linguistic aspects and to explain that a comprehensive and correct language comprehension of the language, in this case Arabic, is essential in understanding many aspects including the legitimacy of terror acts that are generally rooted on the failure to understand the source or Islamic texts.

$D a^{\prime} w a h$, literally means a call or invitation, in Islamic terminology refers to the form of persuasion to change the attitude of society and adapt to God's command as brought by the Prophet Muhammad9. Similarly,

${ }^{6}$ D.C Hofmann, 'The Study of Terrorist Leadership: Where Do We Go from Here?', Ournal of Criminological Research, Policy and Practice, 3.3 (2016), 208-21 <https://doi.org/https:// doi.org/10.1108/JCRPP-09-2016-0018>.

${ }^{7}$ Hofmann, p.208-221.

8 S Ahmad Husin, 'The Importance and Roles of Linguistics in Islamic Studies (Integration of Linguistics with Religious Studies)', Khazanah Journal, 12.1 (2014).

9 Sukron Kamil, "Language and Typology of Dakwahist Islamic Fundamentalisme: The Study of Arabic Loanwords in the Religious Book of Jamaah Tabligh, Insaniyat" Journal of Islam and Humanities, vol.1, no.1, November 2016 
language plays a major role in $d a^{\prime} w a h$ as the easiest, fastest, and most effective form of persuasion, therefore the type, standard of language used and the style of expression and so on contributes. Preachers are those who have the ability to convince people of the target of their $d a^{\prime} w a h$, to influence their decisions and change their attitudes toward many important issues. In recognition of this fact, Allah (SWT) consecrates in the Qur'an [16: 125] that one should pay attention to the phrase he uses and adheres to the concept (arguing gently) on preaching the Islam: "call (humankind) into the way of your Lord with wisdom and good lessons and dispute them in a good way. Your Lord is He who knows better than who is lost from His ways, and He is the one who knows the guided". A preacher should not only being qualified by having high capabilities, but also his eloquence on the rules of grammar and the style of language in which he delivers the messages of God to the intended societies. All of these qualities help the preachers convincing the people to change their attitudes according to the interests of the preachers ${ }^{10}$.

The relevance of linguistic standards and translation of the Qur'an to verses are potentially used as a media to legitimize acts of violence in the name of Islam is an important theme that needs to be studied academically. In order to understand how the events of this misinterpreted messages need to take into account the standard of language usage by the bearers of religious messages (preachers). The use of a standard language is quite pivotal in the dissemination of the speaker's messages, in addition to the speaker should also consider in every act of language to specific types of the recipient community, whether they include the community of knowledgeable or stupid, illiterate and elite or materialist society etc. This fact requires the preachers to always recognize different levels of society. Religious communities in their understanding depend on the written and oral discourses, in addition to the level of vocabulary that is not too difficult to understand, the simple ideas conveyed should also be straightforward and correct. Certainly, this stage of delivery of messages does not obviate the need to use the correct, relevant and beautiful style.

Nonetheless, the concept or method that intertextuality may reflect cannot be described authoritatively. Allen ${ }^{11}$ explicitly says in his discussion on intertextuality that it is one of the most frequently used and abused terms in the critical vocabulary of today." Intertextuality, which originally resonated in the field of critical theory, goes beyond its boundaries because

\footnotetext{
1999).

10 Abdussalam and Ahmed Shehu, Islam and Language (Al-Hilal Publishing,
} ${ }^{11}$ Graham Allen. (2000). Intertextuality. London: Routledge, p.2 
different scientific disciplines have adopted and adapted that idea. Bakhtin's seminal works have largely inspired Kristeva in the late 1960s to correlate with the term intertextuality, for which Kristeva is now openly recognized. Bakhtin ${ }^{12}$ argues that every use of language is essentially immersed in a wider dialog where "the utterance is linked not only to the preceding, but also to the subsequent ties in the chain of speech communion"13.

To be able to study the phenomenon, the researcher needs to see cases of language usage by radical Islamist preacher from the linguistic standpoint. Fairclough argues that Critical Discourse Analysis (CDA) views discourse as text, discourse practice and social practice ${ }^{14}$. In line with Fairclough, the use of CDA to examine texts is an attempt to understand the changing practices of language use (discourse) related to social practice and socio-cultural change (further called intertextuality interpretation). A text may potentially change into different forms at different times because it is influenced by changes in social, political and cultural contexts ${ }^{15}$. Related to the theoretical opinion, the analysis of critical discourse on the phenomenon of preaching the message of da'wah by Islamist radical is believed to produce a comprehensive study that can counter or as a deradicalization of the discourse about Islam which is still viewed by the people who only know Islam and judge the practice of Islamists from a mere radical side.

Abdillah ${ }^{16}$ exposed the approach used to view the Quranic verses sometimes used as a rationale for religious abuse. Abdullah used the thematic approach to scriptures, mostly used as justification for religious radicalism and interpreted in conjunction and seeking the meaning of the revealed texts from historical aspects (asbab an-nuzul) and hermeneutics. In his research, Naharong17 expanded on aspects of religious / holy terrorism or modern terrorism, indicating that, according to some scholars, religion has little to do with terrorism; religion is in reality innocent and is only the

12 Mikhail Bakhtin, (1981). The dialogical imagination. Translated by Emerson, C. and Holquist, M.,University of Texas press: USA.

13 see Voloshinov, Marxism and the philosophy of language, (Harvard University Press, 1973).

${ }^{14}$ Norman Fairclough, Discourse and Social Change (Polity Press, 1992).

15 Teun van Dijk, "Discourse as social interaction", (Sage, 1997), pp. 258 - 284

16 Junaidi Abdillah, "Radikalisme Agama: Dekonstruksi Tafsir Ayat-Ayat "Kekerasan" dalam Al-Qur'an, Kalam: Jurnal Studi Agama dan Pemikiran Islam, 8, No. 2, (Desember 2014), pp. 281-300

17 Abdul Muis Naharong, "Terorisme atas Nama Agama”, Jurnal Refleksi, 13, No. 5, (Oktober 2013), pp.593-622 
target of reckless political activists. Through a historical study of the verses (asbab an-nuzul), Lufaefi ${ }^{18}$ reinterpreted the Qur'anic verses that were justified in the name of religion as promoting verses of acts of violence, in reality there was not one of the Qur'anic verses that encouraged, let alone, violence, terrorism and radicalism. The current study offers a new methodological perspective and view of religious extremism activities which legitimize acts of violence as a jihad in defense of Islam.

This study used a method of interpreting the Qur'anic verses based on Fairclough's Intertextuality Discourse. The Qur'anic verses have often been used as the basis of justification for acts of terror by Islamic extremists. Before continuing this work, the researcher should discern formal and material objects in this paper to make it clearer. The material object in this study is the Qur'an that refers to the command of Jihad and fights the enemies of Islam. The Discourse Intertextuality-based analysis process has methodical steps in interpreting the Qur'an. First, a researcher must keep an eye on the language used. If the topic is the Qur'an texts, the researcher pays attention to understanding the Arabic linguistic aspects from a moderate perspective. It needs intertextuality to be able to deepen the interpretation, namely by comparing the core vocabulary with other words in different verses. The researcher also takes note of the revealed verse's historical context, both macro and micro. Hence a verse's historical context may be an analysis of the environment of the community at that time. Then the researcher explores the maghza (the purpose or message that fits the current context in the text). In order to be able to know the current context, the verse must be examined historically when it was revealed and attention must be paid to the language of the text in this study.

\section{B. Theoretical Underpinnings}

Fairclough ${ }^{19}$ offers three different types of analysis. In the text area, descriptions are used to do text analysis to get an idea of how the text is presented. At this description stage, Fairclough ${ }^{20}$ also emphasized the importance of investigating the process of producing text that covers the socio-cultural context that underlies the birth of the text.

18 Lufaefi, "Telaah Penafsiran Ayat-Ayat Kekerasan: Upaya Mewujudkan Perdamaian dalam Bingkai Keindonesiaan", Jurnal Refleksi, 16, No. 1, (April 2017), pp.1-28

${ }^{19}$ Fairclough, p.27

${ }^{20}$ Fairclough, pp. 97-100. 
Critical Discourse Analysis (Source: Fairclough, 1995)

As a means of seeing how the discourse orders is structured and restructured, the concept of intertextuality is important to Fairclough ${ }^{21}$. The ability to generate social change is the importance of intertextuality. Julia Kristeva stressed that intertextuality requires "history (society) to be incorporated into a text and a text into history," as quoted by Fairclough ${ }^{22}$ The "insertion of text into history" means the existence of texts that respond to and accentuates previous texts which show the role of texts in creating new history through social change and its role in shaping the subsequent texts. Technically, the intertextual relationships have several important characteristics. First, the relation between one text and another is reciprocal, in which the meaning of each other is determined by both one text and another group of texts. Second, the text or genre group becomes the context within which the text is produced and interpreted. Thirdly, some text contextual factors could act as metalingual indicators. Fourthly, the text may be read differently or contrary to the context and linked to a different set of texts 23 .

${ }^{21}$ Norman Fairclough, Discourse and Text: Linguistics and Intertextual Analysis (London: Sage, 1997).

${ }^{22}$ Fairclough, p.102

23 Tony Thwaites and, "Warwick Mules. Introducing Cultural and Media Studies", (Palgrave, 2002). p.98 


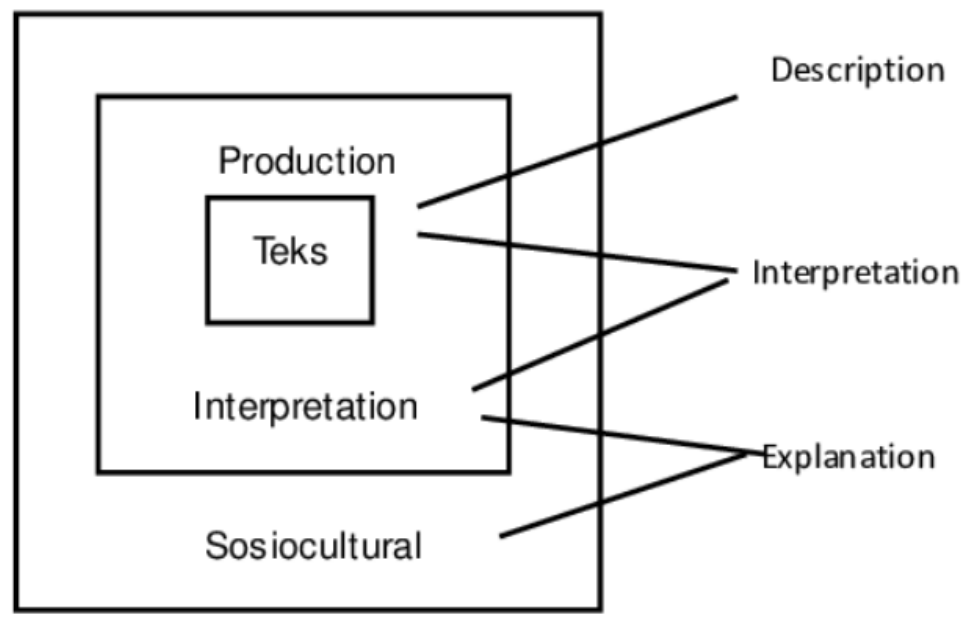

\section{Linguistic Understanding of the Islamic Texts}

The study of texts is part of the art of understanding the message, the events and how human understanding of the texts and the text sections serves as the mobilizing force in society. Islam places its message on the texts of the Qur'an and the prophetic hadiths. From this text Islam is understood by humans. Unlike the text of history and civilization, the teachings of Islam are believed to be divine teachings have a holistic space in which the messages contained in his teachings focused on understanding the mind of God or His wisdom. Religious teachings according to Gianni Vattimo are inseparable from the discourse of interpretation. Religion from the beginning of the emergence is inseparable from the deconsruction understanding of the text ${ }^{24}$. So that anthropology, sociology and human history bias is inseparable from the process of understanding religious texts. The text of Islamic teachings is understood to have two sides namely qod'iyah (absolute comprehension) and dhoniyah (understanding of multi interpretive texts). Two patterns of understanding Islamic texts color the way Islamic teachings are understood. Hegemony as well as its claims to the text making Islam a bourgeois teaching and some groups believes in Islam as a final understanding. This pattern of understanding makes Islam its text an exclusive teaching 25 .

One of the factors causing the emergence of radical groups in Islam is connected with the reality of Islamic sources which essentially needs to be interpreted in the context of Islamic societies and requires dynamic reading

${ }^{24}$ Gianni Vattimo and Piergiorgio Paterlini, Not Being God. A Collaborative Autobiography, Trans. by William McCuaig (Columbia University Press, 2010).

25 PPI Dunia.“Teks dan faham Radikalisme ajaran Islam”, (July 17, 2017). 
and prospective production of the meaning of a text. Gadamer develops an understanding of the sign (text) into a linguistic word with a statement of being understood to be a language; a sign (text) is a meeting with existence through language. The core of the sign lies in the mindset so that the high value of a mark lies in the author's mind, so that the understanding of the text is not the full face of the doctrine.

Our world view is shaped by our language community in addition to the language structure and vocabulary we use. Words and phrases affect what we observe around us - both our religious viewpoint and include how we understand texts that legitimize an action etc ${ }^{26}$. Cross-cultural communication, for example, becomes difficult if we do not capture the nuances of the translated words. In this section the author tries to relate a narrow understanding, the lack of insight between the radicalism and Islam of radical groups such as ISIS has an impact on acts of terrorism.

The Muslim world community believes the language of the Qur'an is Arabic. This is also affirmed in the sources of Islam, one of them in the Qur'an Surah Yusuf verse 2 "innaa anzalnaahu qur: aanan 'arabiyyan la'allakum ta'qiluun" (meaning: Truly We bring it down in the form of the Qur'an with Arabic, so you might understand it). If we relate to acts of terrorism rooted in a radical understanding of Arabic-language texts and used as a basis for legitimizing acts of irreverence in the name of Religion by an organization composed of people who claim to be Arabs. Surely this phenomenon actually raises the question, what is the linguistic difference between the Arabic languages used as a medium of a daily communication by the Arab society with the Arabic language of the Qur'an?

Muslims recognize that the language of the Qur'an is a miracle (I'jaazul Qur'an), even to suit the language, at the early time of Islam, there were none of the Arab poets at was able to create a surah or chapter alike. In many verses, the God through Qur'an has invited them to make the composition of language like the Qur'an, but no one is able to do so (Surah at Thur verse 34), even down to ten letters are also incapable (Hud, verse 13) the latter only asked to make a single letter, that no one was able to do so (al-Baqarah: 23). If any of the poets are able to do so, of course we can see the results of their work at this time. In fact the vocabulary used to write Arabic and Quranic languages is no different; the Arabic grammar arrangement is also no different from the structure used by the Quranic language. The Arabs also know that between the two there is no difference from the elemental side of the language. However, why were the Arab

26 Rebecca Rogers, "Discourse Analysis in Education, (Lawrence Erlbaum Associates, 2004), p.121 
poets not able to compose the same literary works with the language of the Qur'an? The difference is the form of the words choice (diction use). The God of the Moslems has chosen special words in the Qur'an that are not only beautiful in the series, as well as the meaning contained as a consequence of the word choice that makes it different from endemic Arabic. Thus, this is also about the structural choices under the decoration of the revelation spirit, making the structure of the grammar of the Qur'an cannot be equaled by the Arabic people ${ }^{27}$.

The above statement of language religiosity implies the intention that not all Arabs really understand the Qur'an even in their daily use of the language. The bluntness of Islamic knowledge is the reality of extremist groups both within the reach of Arabic knowledge and Islamic law, but there are only young people who are passionate in fulfilling their individual and communal desires. This is also, as some academic studies show, that Religion is not the only reason the group has acted radically among the Muslims. The latest evidence suggests that those who travel to Syria or Iraq to join extremist groups such as ISIS or the Defenders Front alNusra are extremist groups dominated by youth with little understanding of Islamic doctrine and legalizing violence in their actions ${ }^{28}$.

As for the language it shows relative to the interpretation of its society as well as the more prominent Islamic Daulah Islamiyah fighters known as ISIS, especially those comprised of young people coming from non-Arab countries. Many cases show more than one word in Arabic in the Qur'an is often paired with just one word in Indonesian because of the demands to adapt small samples such as the connector "and The study of texts is part of the art of understanding the message, the events and how human understanding of the texts and the text sections serves as the mobilizing force in society. Islam places its message on the texts of the Qur'an and the prophetic hadiths. From this text, Islam is understood by humans. Unlike the text of history and civilization, the teachings of Islam are believed to be divine teachings have a holistic space in which the messages reflected therein teachings focused on understanding the God or His wisdom. Religious teachings according to Gianni Vattimo are inseparable from the discourse of interpretation. Religion from the beginning of the emergence cannot be separated from the deconsruction understanding of the text. So that anthropology, sociology and human

27 Jeffrey T. Kenney, \& Ebrahim Moosa,"Islam in the Modern World" (Routledge, 2014), p.36

28 www.parliament.uk, "Democracy and political Islam", (3 November 2016), https://publications.parliament.uk 
history bias is inseparable from the process of understanding religious texts. The text of Islamic teachings is understood to have two sides namely qod'iyah (absolute comprehension) and dhoniyah (understanding of multi interpretive texts). Two patterns of understanding Islamic texts color the way Islamic teachings are understood. Hegemony as well as its claims to the text making Islam a bourgeois teaching and some groups believes in Islam as a final understanding. This pattern of understanding makes Islam its text an exclusive teaching 29 .

One of the factors causing the emergence of radical groups in Islam is connected with the reality of Islamic sources which essentially needs to be interpreted in the context of Islamic societies and requires dynamic reading and prospective production of the meaning of a text ${ }^{30}$. Gadamer develops an understanding of the sign (text) into a linguistic word with a statement of being understood to be a language; a sign (text) is a meeting with existence through language. The core of the sign lies in the mindset so that the high value of a mark lies in the author's mind, so that the understanding of the text is not the full face of the doctrine. The fundamental thing for Gadamer is the rejection of the "sign" theory in the essence of language, for Gadamer language is the situation, expression and mode of human existence. For Gadamer there are four components that are inseparable from the interpretation towards the texts which is bildung (preunderstanding) communal census (social and cultural aspects) test (balance of instinct, senses and intellectual freedom) judgment (decision from the reader against sign (text) ${ }^{31}$.

\section{Fairclough's Discourse Analysis on Islamic Sharia Interpretation of Jihad}

Language is a media that bridges the written text or speech in the mind of the users. Ideologically infiltrated language is like a tool between text and structures, context and structure and between discourse and society ${ }^{32}$.Ideology defines how the terrorist group views the world around them and recognizes their opponents by describing and justifying why those people or organizations are legitimate attack targets. In this case,

${ }^{29}$ PPI Dunia.“Teks dan faham Radikalisme ajaran Islam”, (July 17, 2017).

30 Sayyid Qutb, "Basic Principles of the Islamic Worldview", trans. Rami David. North Haledon, N.J., (Islamic Publications International IPI, 2006).

31 Mick Smith, "Lost for Words? Gadamer and Benjamin on the Nature of Language and the 'Language' of Nature", Environmental Values, 10, No. 1 (February 2001), pp. $59-75$

32 Gilbert Weiss and Ruth Wodak, Critical Discourse Analysis: Theory and Interdisciplinarity (New York: Palgrave Macmillan, 2003). 
religion is also part of the ideology that motivates and justifies acts deemed to be terrorism, as do the other ideologies (nationalism, communism, separatism, etc. ${ }^{33}$. In reality, it is hard to denounce religion's relation not only to seek to bring about peaceful human beings, but to cause violence among believers as we frequently see religion as an ideological justification and a symbolic explanation of violence committed by certain religious groups.

Most of the debates between radical and non-radical groups are not on religious principles alone, but also because of their implications for actual behavior based on detailed legal interpretations of those principles. The interpretation of this law is debatable. Even among the moderate Islamic scholars who condemn acts of terrorism they recognize the obligation of jihad, the actuality in traditional Islamic law (Sharia) to establish jihad commands should be considered with great care. He emphasized that linguistic competence is an important means of understanding Islamic texts. For example in the etymology of the word jihad (from the root word jahada) actually means "to act sincerely" 34, which do not mean "holy war," and does not necessarily, have a militant connotation $^{35}$. For most of the Islamic groups, jihad is defined as a war against Islam's enemy, so fighting against all the enemies of Islam is a noble act of Jihad. Disputably, the word jihad is an accusation which denies and replaces Islam. In fact, if we trace the Qur'an word for jihad it can't be simplified and identified with war (qital). War is always about physical defense and resistance, whereas jihad has wider meaning. Hossein Nasr notes that out of 36 verses of the Qur'an, (around) 39 words are referred to as Jahada with numerous aspects. The remaining word applies to all physical and spiritual practices and concerted attempts to bring the will of God into the earth, which essentially consists in the creation of noble moral ideals, from justice to the peace and prosperity of mankind. ${ }^{36}$

33 Adam Dolnik and Rohan Gunaratna, "On the Nature of Religious Terrorism”, 343; Drake, “The Role of Ideology in Terrorists' Target Selection," 56.

34 According to Ibnu Manzur, the words jahada-yujahidu-mujahadah- jihad which mean that one strives earnestly by putting effort into carrying out God's commands (Ibnu Manzur, Lisaan al-'Arab (Kairo: Daar al-Hadiths, 2003), p. 239-41; Anis, et al., al-Mu'jam al-Wasit, Chp. 1, p. 142.)

35 Shamuel Bar, (Tuesday, June 1, 2004), The Religious Sources of Islamic Terrorism, retrieved https://www.hoover.org/research/religious-sources-islamicterrorism

${ }^{36}$ Seyyed Hossein Nasr, "The Heart of Islam: Pesan-pesan Universal Islam untuk Kemanusiaan", (Mizan, 2003), p.313-314. 


\section{E. The Lack of capacity in understanding the Islamic Sources}

Understanding Islam, to some extent, means understanding the Qur'anic texts that Muslims believe is spoken verbally to the Prophet Muhammad as a revelation dating back 1,400s years ago, although the Qur'an is written in Arabic, however, it is very difficult to translate. The difficulty of understanding Islamic sources lies in the difficulty of understanding words that have multiple levels of interpretation that contain layered meanings through interpretive methods derived from authoritative scholars.

Throughout the history of Islamic journey, there have been many phenomenon of abuse and beheading of religious texts (al-Qur'an) for political purposes which ultimately triggered the action of Religious radicalism. However, Islam as Religion has a text that can be seen from different angles. Thus, the heterogeneity of interpretation is inevitable. In such a situation, lately there has been an attempt to "nominate" the kind of interpretation that causes fanaticism. This kind of interpretation is regarded as an undeniable reality. And this can lead to quite serious problems since it is often implied that the various interests behind the interpretation.

Rashid Khalidi, a professor of modern Arab society studies at Columbia University, denied if the Koran justifies Muslims in beheading the enemy. He cites a sentence that is often misunderstood because the verse is used to justify extremist acts, for example by ISIS. In the Qur'an the quotation is found in Surah 47, Verse 4: "Thus, when ye meet with those who disbelieve (in battle), hit their neck". Then when you have conquered them, take them captive and after that you may free them or receive a ransom until the war is over. This is often the case mainly by ISIS and Islamic community organizations and other radical Islamic movements as the basis for a number of acts of violence in the name of Islam. It is precisely the subsequent sentence that the radicals have ignored: "When you really subdue them, bind the prisoners firmly, therefore is the time for good or ransom". Basically, Khalidi asserted that there is nothing in this section that justifies beheading people's heads". This just shows that they do not know anything about Islam and they probably do not know how to read the Qur'an properly“37. Of course, the intertextuality to the discourse should explain the potential meaning of raising scientific consciousness in cases of interpreting Quranic verses that may lead to such extreme views and attitudes. The interdiscursivity is an integral part of the main concept

37TPT.Com "Why Europe has a problem of Islamic State Terrorism", https://www.tpt.org/pbs-newshour 
of critical discourse analysis (CDA) Fairclough. Fairclough ${ }^{38}$ argues that a text is inherently an integral part of the whole intertext. In translation, a translated text is an element closely related to the source text because the translated text is the embodiment of the source text in a different language. Therefore, the source text and the translated text is a manifestation of intertextuality.

The cause of the chaos and upheaval in this world by irresponsible terrorists in the name of Islam is not the Qur'anic verses that encourage people to do that, but the rise in radical understanding of the Qur'anic texts where these people do not understand contextually. Re-understanding and reflecting on religious thinkers does not seem to be enough just to mention Islam as anti-violence. As language and debate observers, the academic community needs to be able to make sure that the verse quoted is deceptive and leaves the meaning of Islam as a saving and non-destructive faith. The story of Hamoud al-Hitar follows illustrating the courage of a cleric in straightening radical hard thinking by visiting the accused terrorists in various prisons in Yemen. "If you can convince me that your thoughts are justified by the Qur'an, then I will join you," challenged al-Hitar to the terrorists. "But if I am the one who convinces you, then you should abandon your hard method". With this method of self-righteous dialogue, al-Hitar succeeded in defusing the radicalism and violent extremism of the Yemeni Al-Qaeda recruits. As a result, since December 2002, terrorist attacks in Yemen have subsided, although Yemen is widely considered to be the capital of terror. "364 youths (terrorist suspects) were released from prison after going through the process of dialogue, and none of them left Yemen to fight again in any field (jihad)," as al-Hitar reported. We can try the method of al-Hitar, at least to know how high our religious beliefs face the thoughts of terrorists. Al-Hitar did not speak in the shaded spaces to say the ultraradic violence was wrong, but went directly to terrorists to complain that the Qur'an never enforces its people against innocent people.

In addition, another Islamic academic, Walled al-Ansary who denounced the message of two fatwa jihad of Osama bin Laden which he called deviate from Islam. "Osama says killing Americans and their allies, both civilian and military, are mandatory," Walleed said. However, the Islamic Shari'ah never recognizes the words `military`and civic. ' "Islam only knows combatants (muqatala) and non-combatants (ghoiro muqatala), and non-combatants are women, children, pastors, parents and the like" Walleed. Thus, al-Waleed, Osama has broken the Islamic law of war. "Irjaf" The Egyptian Mufti (Chairman of Egyptian Ulema Council), Sheikh Ali

${ }^{38}$ Fairclough, 1992, p.24 
Goma, even offers a much more advanced perspective. The world's leading cleric offers a new association for "terrorists" by stripping the label of "jihad" on Al-Qaeda terrorist acts and their affiliates, including Indonesia, with the word "Irjaf". "Irjafiyyun" is the most appropriate translation for 'terrorists', those who cause innocents shock," as Ali Goma once emphasized ${ }^{39}$. From a linguistic perspective, to confirm Ali Goma's perspective, "irjaf" means coward, impostor, and traitor for attacking from behind. "Irjaf only dared to attack the innocent, dishonor action, and very negative." Irjaf is clearly different from war, "as the great scholar emphasized. Ali Goma asserted that this could be a reflection and an important material, if hard ideas should not be countered by weapons and rhetoric, but by examining the roots and meaning of the language use. It is also a message that religionists should take on a wider role in the episodes of further Islamic youth deradicalization ${ }^{40}$. Another important point is that approaching and not behind hate, embracing and not alienating, sorting and not generalizing, is a wise way of extinguishing radicalism and closing the valve of terrorism. This is because, to borrow Chairman of the Foundation of Peace Inscription Noor Huda Ismail who was on a podium with Nasaruddin Umar at the July 29 symposium, the jihad activists are classy. "There is a white jihad, a black jihad, and a gray jihad," as emphasized by Noor Huda. The white group that is the ideologue and core people of the terror movement is almost impossible to deflect, on the contrary the "black" and "the gray" whose spiritual beliefs are not as strong as the white ones, can still be straightened out. Let the "white" be a legal matter, but the "black" and "gray" who are the majority of terrorists in the field, should be approached to abandon violence, as al-Hitar did in Yemen ${ }^{41}$.

Understanding the crisis of the linguistic understanding on the aspects of language use in various cases of the Qur'anic interpretation above emphasizes the importance of studying this phenomenon and then bringing it into the realm of dialogue and intellectuals against terrorism, which it calls soft power. As a form of subtle resistance through critical discourse, there are three important interrelated matters in critical

${ }^{39}$ Abdullah Walid Jumblatt, 'Merits and Limits of Counter-Ideological Work Against Terrorism: A Critical Appraisal', Small Wars E Insurgencies, 28.2 (2017), 297-98.

40 Kevin Carnahan, "Review: Constructing Conflict: A Review Essay, Crescent and Dove: Peace and Conflict Resolution in Islam by Qamar-Ul Huda; Just War on Terror?", Journal of Law and Religion, 28, no.1, (2012-13), pp. 253-266

41 Jafar M. Sidik, "Terorisme, Semiotika dan Bahasa Indonesia”, ANTARANEWS.com, (Selasa, 5 Oktober 2010), 
discourse namely text, context and discourse ${ }^{42}$. Discourse analysis here is to describe text and context simultaneously in a communication process. Intertextuality resides in two formations, namely horizontal formation, linking the text maker with the recipient of the text; and vertical formations, linking text with other texts 43 . Both formations are closely related to the equation of knowledge and meaning at a time and place that has the potential to change. A text is constructed with a specific construct involving the relationship between the text maker and the recipient of the text with the purpose of persuasion, legitimizing or giving a choice on the topic contained in the text.

\section{F. Conclusion}

The importance of linguistic aspects is the instrument in understanding the Islamic texts including the aspects that relate the legitimacy on the acts of terror that are generally rooted on the failure to understand the source or Islamic texts. Throughout the history of Islamic journey, there have been many phenomena of abusing and beheading of the religious texts (al-Qur'an) for political purposes which ultimately triggered the action of religious radicalism. However, Islam as Religion has a text that can be seen from different angles, so the heterogeneity of interpretation is inevitable. The text of Islamic teachings is understood to have two sides namely qod'iyah (complete comprehension) and dhoniyah (multi-interpreted texts understanding). Two patterns of understanding Islamic texts become the spectrum of how the teachings of Islam are fairly understood. Linguistic provides general criticism toward the radicals' interpretations in understanding the Islamic texts. The writers attempted to relate the way such radicalists have been used the God's messages for their purposes and how the critical language study and linguistic relativism contributed a great deal in illuminating the issue regarding this misunderstood the Islamic messages. Then the study ends up with an argument that the radicalism in many groups in Islam is connected with the reality of Islamic sources which essentially needs to be interpreted in the context of Islamic societies and requires dynamic reading and prospective production on the meanings of a sacred text[.]

42 Eriyanto, Analisis Framing: Konstruksi, Ideologi, Dan Politik Media (Yogyakarta: LkiS, 2005).

${ }^{43}$ Julia Kristeva, "Desire in Language: A Semiotic Approach to Literature and Art", (Columbia University Press, 1980). 


\section{REFERENCES}

Abdussalam, and Ahmed Shehu, Islam and Language (Al-Hilal Publishing, 1999)

Eriyanto, Analisis Framing: Konstruksi, Ideologi, Dan Politik Media (Yogyakarta: LkiS, 2005)

Fairclough, Norman, Discourse and Social Change (Polity Press, 1992)

- - , Discourse and Text: Linguistics and Intertextual Analysis (London: Sage, 1997)

Hofmann, D.C, 'The Study of Terrorist Leadership: Where Do We Go from Here?', Ournal of Criminological Research, Policy and Practice, 3.3 (2016), 208-21 <https://doi.org/https:// doi.org/10.1108/JCRPP-09-20160018>

Rois Khanifah, Agus, Teror, Catatan Filsafat Dan Politik Tentang Firman Dan Iman (Yogyakarta: Penerbit Makar, 2016)

$S$ Ahmad Husin, 'The Importance and Roles of Linguistics in Islamic Studies (Integration of Linguistics with Religious Studies)', Khazanah Journal, 12.1 (2014)

Vattimo, Gianni, and Piergiorgio Paterlini, Not Being God. A Collaborative Autobiography, Trans. by William McCuaig (Columbia University Press, 2010)

Weiss, Gilbert, and Ruth Wodak, Critical Discourse Analysis: Theory and Interdisciplinarity (New York: Palgrave Macmillan, 2003)

Zuhdi, Nurdin, 'Hermeneutika Al-Qur'an: Tipologi Tafsir Sebagai Solusi Dalam Memecahkan Isu-Isu Budaya Lokal Keindonesiaan', Jurnal Esensia, 13.2 (2012)

Hossein Nasr, S. The Heart of Islam: Pesan-pesan Universal Islam untuk Kemanusiaan. Bandung: Mizan, 2003.

Jafar M. Sidik, "Terorisme, Semiotika dan Bahasa Indonesia", ANTARANEWS.com, (Selasa, 5 Oktober 2010), http://www.antaranews.com/berita/226849/terorisme-semiotikadan-bahasa-indonesia

Gadamer, Hans Georg. Philosophical Hermeneutics, Translated and Edited by Graddol, David, Thompson, L. \& Byram, M. (Eds.), Language and Culture, Cleved on: Multilingual Matters. Linge, David E. Berkeley, Los Angeles, London: University of California, 1977.

Kamil, Sukron. "Language and Typology of Dakwahist Islamic Fundamentalisme: The Study of Arabic Loanwords in the Religious Book of Jamaah Tabligh, Insaniyat" Journal of Islam and Humanities, 1, no.1, (November 2016)

Khanifah, Agus Rois, "Teror, Catatan Filsafat dan Politik tentang Firman dan Iman", Jakarta, Rembang Makar, 2016. 
Kristeva, Julia. Desire in Language: A Semiotic Approach to Literature and Art. New York: Columbia University Press, 1980.

PPI Dunia. "Teks dan faham Radikalisme ajaran Islam", (July 17, 2017), http:/ / ppidunia.org/teks-dan-faham-radikalisme-ajaran-islam/

Qutb, Sayyid. Basic Principles of the Islamic Worldview, [trans. Rami David].

North Haledon, N.J.: Islamic Publications International IPI, 2006.

Rasyid, M. HTI Gagal Paham Khilafah. Jakarta: Pustaka Compass, 2016.

Rogers, R. Discourse Analysis in Education. New Jersey: Lawrence Erlbaum Associates, 2004.

Rois, Agus. Teror, Catatan Filsafat dan Politik tentang Firman dan Iman. Yogyakarta: Penerbit Makar, 2016.

Serafim, A., "Terrorism - A Cultural Phenomenon?" Connections, 4, no. 1, (Spring 2005): 61-74

Shmuel Bar, "The Religious Sources of Islamic Terrorism", (Tuesday, June 1, 2004), http://www.hoover.org/research/religious-sourcesislamic-terrorism

Smith, M., (2001), Lost for Words? Gadamer and Benjamin on the Nature of Language and the 'Language' of Nature, Environmental Values, 10,

(1) (February 2001): 59-75, https:/ / www.jstor.org/stable/30301784 van Dijk, T. Discourse as social interaction. London: Sage, 1997.

Vattimo, Gianni, and Piergiorgio Paterlini, Not Being God. A Collaborative Autobiography, Trans. by William McCuaig (Columbia University Press, 2010)

Venkatraman, A. “Religious Basis for Islamic Terrorism: The Quran and Its Interpretations", Studies in Conflict $\mathcal{E}$ Terrorism, 30, no.3, (2007): 229248

Voloshinov, Marxism and the philosophy of language. [Trans. by Matejka, L. and Titunik, I.], Cambridge: Harvard University Press, 1973).

Walid Jumblatt, Abdullah, 'Merits and Limits of Counter-Ideological Work Against Terrorism: A Critical Appraisal', Small Wars $\mathcal{E}$ Insurgencies, 28.2 (2017), 297-98

Weiss, Gilbert, and Ruth Wodak, Critical Discourse Analysis: Theory and Interdisciplinarity (New York: Palgrave Macmillan, 2003)

Zuhdi, Nurdin, 'Hermeneutika Al-Qur'an: Tipologi Tafsir Sebagai Solusi Dalam Memecahkan Isu-Isu Budaya Lokal Keindonesiaan', Jurnal Esensia, 13.2 (2012) 